\title{
Optimization of reinforcement steel supply to precast concrete plants
}

\author{
Aleksander Nicał ${ }^{1}$ \\ Received: 19 December 2018 / Accepted: 15 February 2019 / Published online: 13 March 2019 \\ (C) The Author(s) 2019
}

\begin{abstract}
In addition to aggregates, cement, and water, reinforcing steel is one of the key building components of precast products. Steel price fluctuations observed on global markets have a large impact on the cost of production of precast products made of reinforced and prestressed concrete. An important issue is, therefore, the proper planning of steel orders and deliveries to the precast concrete plants. A significant number of competing warehouses and construction warehouses offer diversified steel prices, which are subject to frequent changes in relatively short periods. This results in a problem in the selection of an appropriate procurement strategy by precast concrete plants. An additional unfavorable factor is the ordering of reinforcing steel that is too large in relation to the demands of the precast concrete plants, resulting in high costs of its storage in the warehouses or storage yards. In this paper, the issues of optimal planning and delivery of plain, ribbed, and prestressing steel were discussed. For the research and calculation purposes, supplies of steel from four wholesalers to four different precast concrete plants were assumed. In addition, the types of steel and the class of bars used to reinforce the elements were discussed. A different level of unit prices for the purchase and delivery of steel in each warehouse and a different demand for each of the four concrete plants were also assumed. As a result of the analyses carried out, a model was developed, including the strategy of purchasing and supplying plain, ribbed, and prestressing steel with the assumption of minimum costs.
\end{abstract}

Keywords Precast concrete plant $\cdot$ Reinforcement steel $\cdot$ Optimization

JEL Classification PACS $\cdot 89.20 . \mathrm{Kk} \cdot 87.55 . \mathrm{de}$

\section{Introduction}

Steel has a very important function in building constructions, providing the possibility of transferring the tensile stresses occurring in the cross section of the element. Depending on the type of function performed in the facility, the element has a different degree of reinforcement, which also translates into costs related to the purchase of steel. In the case of a continuous footing made of a reinforced concrete for a single-family building, the cost of steel purchase may account for about $15 \%$ of all costs (Jankowski and Antkiewicz 2018). Reinforcement assembly for building elements is associated not only with the use of

This article is part of the Topical Collection on Geo-Resources-EarthEnvironmental Sciences

Aleksander Nicał

a.nical@il.pw.edu.pl

1 Faculty of Civil Engineering, Warsaw University of Technology, Warsaw, Poland different types of reinforcing bars but also with different technologies of its implementation. In reinforced concrete structures, it is necessary to ensure, among other things, a minimum concrete cover for reinforcing bars, whereas with prestressed constructions, it is also important to program the appropriate tension for the prestressing steel strands. This is related to the fulfillment of many conditions, such as, for example, selection of the prestressing force and calculation of losses of the prestress. The fulfillment of these conditions, as well as the ensuring of an appropriate dimensional tolerance of the elements, with the simultaneous reproducibility in the production process, contributes to the use of prefabrication technology. Generally, the challenges posed by precast production technologies are related to raising up the production efficiency and shortening the time of performing production activities and concrete curing processes, as well as prefabrication deliveries to the right time and place at the construction sites, in accordance with the justin-time methodology (Shin et al. 2011). Over the last years, the amount of information necessary for construction processes has significantly increased. Some support came with the introduction of technology radio-frequency identification (RFID) and 
wireless sensor network (WSN), which in the future may play a key role in improving collection and sharing of information in the supply chain process (Jaselskis and El-Misalami 2003; Song et al. 2006; Yagi et al. 2005; Chin et al. 2005; Sangyoon et al. 2008). The influence of the building information modeling (BIM) on the precast concrete industry, observed in recent years, needs to be considered too (Foremny and Nicał 2013; Nicał and Wodyński 2016; Grzyl et al. 2017). These technologies contribute to the increasing improvement of the enterprise resource planning (ERP) method in concrete precast plants, including the material requirements planning (MRP) standard, which is responsible for resource planning in the preproduction phase (Nicał 2018a, 2018b). Although BIM and RFID enriched ERP, some pragmatic problems still cannot be solved (Zhiliang and Zhitian 2015). A proper scheduling and the right amount of raw material supplies, resulting from the current needs of the precast concrete plant, are significant so that the production is profitable. Some research areas address the development of models combining optimal scheduling for production and internal and external transport as well as planning and further resource allocation strategies with regard to time-cost optimization (Radziszewska-Zielina and Kania 2017). However, the problem of using inaccurate planning methods, insufficient resource utilization, and overstocking was noticed many years ago (Dawood 1993; Chan and $\mathrm{Hu}$ 2002) and, in many cases, is still present. A very important issue is also the appropriate choice of steel reinforcement, which should take into account the current state of it, such as, e.g., the quality of the external surface, and in particular the elimination of corroded places. It is also reasonable to introduce methods of selecting steel suppliers who will meet the predetermined criteria, depending on the preferences of the decision-maker. Such solutions have already been developed, among others, in the automotive industry using fuzzy logic (Toklu 2018). The growing influence of fuzzy set theory in construction projects is also worth noting in which, apart from high steel consumption, the issues of risk factors are discussed (Ibadov 2016; Ibadov 2018). The wrong choice of steel reinforcement suppliers affects not only the costs and duration of construction projects but also the durability of the entire reinforced concrete or prestressed structure. Determining the criteria for selecting steel suppliers is, therefore, an area for further research, which must be expanded, including the aspects of the use of waste in the production cycle and the impact of different additives on the mechanical properties of steel. Considering the supply needs as well as the qualitative and technological needs of reinforcing steel, the problem becomes complex. Therefore, it is necessary to develop a tool which enables to find the optimal procurement strategy, minimizing the cost of purchase, while meeting the needs of the concrete plants and taking into account the steel reinforcement resources. The research assumes that all steel reinforcement warehouses offer the same steel in terms of quality and impact on the mechanical properties of the entire building element and aspects of waste utilization. The criteria assessed were only the purchase and delivery of steel reinforcement of various types and cross-sectional diameters from various reinforcement steel warehouses.

\section{Reinforcement steel for precast concrete}

Depending on the chemical composition, the type of production technology, the shape of bars, and other factors, reinforcing steel has mechanical, strength, and utility characteristics. They determine its usefulness and scope of application (Bielawski et al. 1982). Depending on the type of steel product planned in the production process, the following plastic working processes of steel are distinguished: rolling, drawing, forging, and pressing. In addition, rolling can be carried out either cold or hot. The most important mechanical properties of steel, among others, are yield strength of the steel and the tensile strength, ductility, and fracture toughness (Żmuda 2016). The detailed scope of requirements in the field of mechanical properties of steels is defined in technical standards and can be varied in many countries around the world.

\section{Classification and characteristics of steel used in precast elements}

Generally, due to the profile, two types of reinforcing steel are distinguished: smooth and ribbed. In countries where, e.g., "EN-1992-1-1 - Eurocode 2: Design of concrete structures" (EUROPEAN COMMITTEE FOR STANDARDIZATION 2008) is applicable, it is not allowed to use smooth bars for the reinforcement. Their use is possible in diagonals of welded trusses, and the admission to trading takes place only as a semi-finished product (Więch 2013). The diameters of the smooth bars are usually in the range of 8 to $32 \mathrm{~mm}$, while the ribbed bars range from 6 to $40 \mathrm{~mm}$. Smooth bars are made of steel with a lower yield strength of the steel. Reinforcing steel bars are hot rolled. Reinforcing steel may be divided into three classes due to its ductility:

(A) Reinforcing steel with low ductility

(B) Reinforcing steel with medium ductility

(C) Reinforcing steel with high ductility

In addition, the properties of steel also include its weldability and suitability for use in structures subjected to repeatedly variable loads. An exemplary classification of steel grades is shown in Table 1.

Strength requirements for reinforcing steel used for the prestressed concrete structures are significantly higher. As reinforcement, plain, indented, or ribbed reinforcement 
Table 1 Classification of steel grades according to $\mathrm{PN}-\mathrm{EN} 1992$ $1-1: 2: 2008$

\begin{tabular}{lllll}
\hline Steel grade & $\begin{array}{l}\text { Mark of } \\
\text { the steel grade }\end{array}$ & $\begin{array}{l}\text { Nominal diameter } \\
\text { of a reinforcing } \\
\text { bar } \varphi(\mathrm{mm})\end{array}$ & $\begin{array}{l}\text { Characteristic yield } \\
\text { strength of reinforcement } \\
f_{\text {yk }} \text { or } f_{0.2 \mathrm{k}}(\mathrm{MPa})\end{array}$ & $\begin{array}{l}\text { Tensile strength } \\
\text { of reinforcement } f_{\mathrm{t}}(\mathrm{MPa})\end{array}$ \\
\hline A & BST 500 KR & $6 \div 12$ & 500 & 550 \\
& B 500 A & $4 \div 16$ & 500 & 550 \\
& BST 500 S(A) & $8 \div 32$ & 500 & 550 \\
& RB 500 & $6 \div 40$ & 500 & 550 \\
RB 500 W & $6 \div 40$ & 500 & 550 \\
B & BST 500 S(B) & $8 \div 32$ & 500 & 550 \\
& RB 400 & $6 \div 40$ & 400 & 440 \\
RB 400W & $6 \div 40$ & 400 & 440 \\
RB 500 WZ & $8 \div 32$ & 500 & 550 \\
BST 500 WR & $8 \div 32$ & 500 & 550 \\
34 GS & $6 \div 32$ & 410 & 550 \\
B 500 SP & $8 \div 32$ & 500 & 575 \\
35G2Y & $6 \div 20$ & 410 & 550 \\
20G2VY-b & $6 \div 28$ & 490 & 590 \\
\end{tabular}

wires, bars, and strands made of high-carbon steels are used, which are subjected to cold pull processes. The wires are then connected and spirally twisted to form strands, generally 3- or 7-wire strands. An exemplary classification is shown in Table 2.

Additionally, in the production of precast reinforced concrete elements, depending on their type, mesh for reinforcing plate elements may be used. Their width is usually matched to the width of the element. They consist mainly of supporting and transverse bars; the dimensions of which may vary. Exemplary types of meshes with the size of the apertures are shown in Table 3.
Other types of reinforcement used in the production processes of precast concrete elements include, among others, the following:

- Flat steel skeletons - consisting of supporting bars and short transverse bars

- Welded wire reinforcement - made up of an individual, closely spaced rods connected together at predetermined gaps by mounting rods

- Spatial steel skeletons - performed by bending welded meshes or flat steel skeletons and by joining short transverse bars of parallel set skeletons

Table 2 Examples of strands for reinforcement of prestressed structures according to PrEN 10138-1: 2000 (European Commitiee for Standardization 2000a) and PrEN 10138-3: 2000 (European Commitiee for Standardization 2000b)

\begin{tabular}{|c|c|c|c|c|c|}
\hline Steel grade & $\begin{array}{l}\text { Mark of } \\
\text { the steel grade }\end{array}$ & Types of prestressing steel & $\begin{array}{l}\text { Nominal diameter } \\
d(\mathrm{~mm})\end{array}$ & $\begin{array}{l}\text { Tensile strength } \\
R_{\mathrm{m}}(\mathrm{MPa})\end{array}$ & Surface configuration \\
\hline \multirow[t]{7}{*}{ A } & Y1960S3 & 3-wire strand & 5.2 & 1960 & Plain or indented \\
\hline & Y1860S3 & 3-wire strand & $6.5-6.8-7.5$ & 1860 & Plain or indented \\
\hline & Y1860S7 & 7-wire strand & $7.0-9.0-11.0-12.5-13.0-15.2-16.0$ & 1860 & Plain or indented \\
\hline & Y1770S7 & 7-wire strand & $15.2-16.0-18,0$ & 1770 & Plain or indented \\
\hline & Y1860S7G & 7-wire strand & $12.7-15.2$ & 1860 & Plain \\
\hline & Y1820S7G & 7-wire strand & 15.2 & 1820 & Plain \\
\hline & Y1700S7G & 7-wire strand & 18.0 & 1700 & Plain \\
\hline \multirow[t]{6}{*}{ B } & Y2160S3 & 3-wire strand & 5.2 & 2160 & Plain or indented \\
\hline & Y2060S3 & 3-wire strand & 5.2 & 2060 & Plain or indented \\
\hline & Y1960S3 & 3-wire strand & 6.5 & 1960 & Plain or indented \\
\hline & Y2160S7 & 7-wire strand & 6.85 & 2160 & Plain or indented \\
\hline & Y2060S7 & 7-wire strand & 7.0 & 2060 & Plain or indented \\
\hline & Y1860S7 & 7-wire strand & 9.0 & 1860 & Plain or indented \\
\hline
\end{tabular}


Table 3 Examples of reinforcing meshes for reinforced concrete structures (Konsorcjum Stali 2018)

\begin{tabular}{|c|c|c|c|c|c|c|}
\hline Mark & Wire (mm) & Length (rm) & Width (rm) & Aperture dimensions (mm) & Sheet weight $(\mathrm{kg})$ & Weight of $1 \mathrm{~m}^{2}(\mathrm{~g})$ \\
\hline Q131A & 5 & 5 & 2.15 & $150 \times 150$ & 22.5 & 2.09 \\
\hline Q188 2.4 × 1.2 & 6 & 2.4 & 1.2 & $150 \times 150$ & 7.73 & 2.68 \\
\hline Q188 A & 6 & 5 & 2.15 & $150 \times 150$ & 32.4 & 3.01 \\
\hline Q188 6×2.4 & 6 & 6 & 2.4 & $150 \times 150$ & 42.6 & 2.96 \\
\hline Q283 & 6 & 6 & 2.4 & $100 \times 100$ & 63.94 & 4.44 \\
\hline Q142 & 6 & 6 & 2.4 & $200 \times 200$ & 32 & 2.22 \\
\hline Q335A & 8 & 5 & 2.15 & $150 \times 150$ & 57.7 & 5.37 \\
\hline Q335 6× 2.4 & 8 & 6 & 2.4 & $150 \times 150$ & 75.84 & 5.27 \\
\hline Q503 & 8 & 6 & 2.4 & $100 \times 100$ & 113.8 & 7.90 \\
\hline Q252 & 8 & 6 & 2.4 & $200 \times 200$ & 56.9 & 3.95 \\
\hline Q523 & 10 & 5 & 2.15 & $150 \times 150$ & 90.05 & 8.38 \\
\hline Q785 & 10 & 6 & 2.4 & $100 \times 100$ & 172.5 & 11.98 \\
\hline Q523 6 × 2.4 & 10 & 6 & 2.4 & $150 \times 150$ & 118.46 & 8.23 \\
\hline Q754 & 12 & 6 & 2.4 & $150 \times 150$ & 170.5 & 11.84 \\
\hline
\end{tabular}

- Simple, bent bar reinforcement and hooks used as a supplement to transfer the necessary loads

- Connecting inserts used to connect precast concrete elements together (Bielawski et al. 1982)

\section{Steel price analysis}

The price of steel depends on many factors, among which the following can be mentioned:

1. The level of competition on selected domestic markets

2. The level of raw material prices (i.e., iron ore, coking coal)

3. The level of demand and supply on local and world markets

4. Currency exchange rates in relation to the dollar
5. Regional and local legal regulations in the field of steel import and export

In addition, the price of reinforcing bars (rebar) is influenced by their diameter and steel grade. Rods made of high-strength steel are more expensive than those made of lower-grade steel. However, rods with larger diameters are cheaper than rods with smaller diameters. The average price of carbon steels in the world in the last 12 months ranged from about $\$ 550$ to $\$ 700$ for a wire rod (mesh) and from about $\$ 530$ to over $\$ 640$ for rebar for a metric ton (1.1023113 tons). A detailed list is shown in Fig. 1 (MEPS - World Carbon Steel Prices 2018).

The price of rebar is also diversified in the way it is delivered. The Incoterms (International Commercial Terms) in the field of steel have defined, i.e., the following rules for the mode of transport:

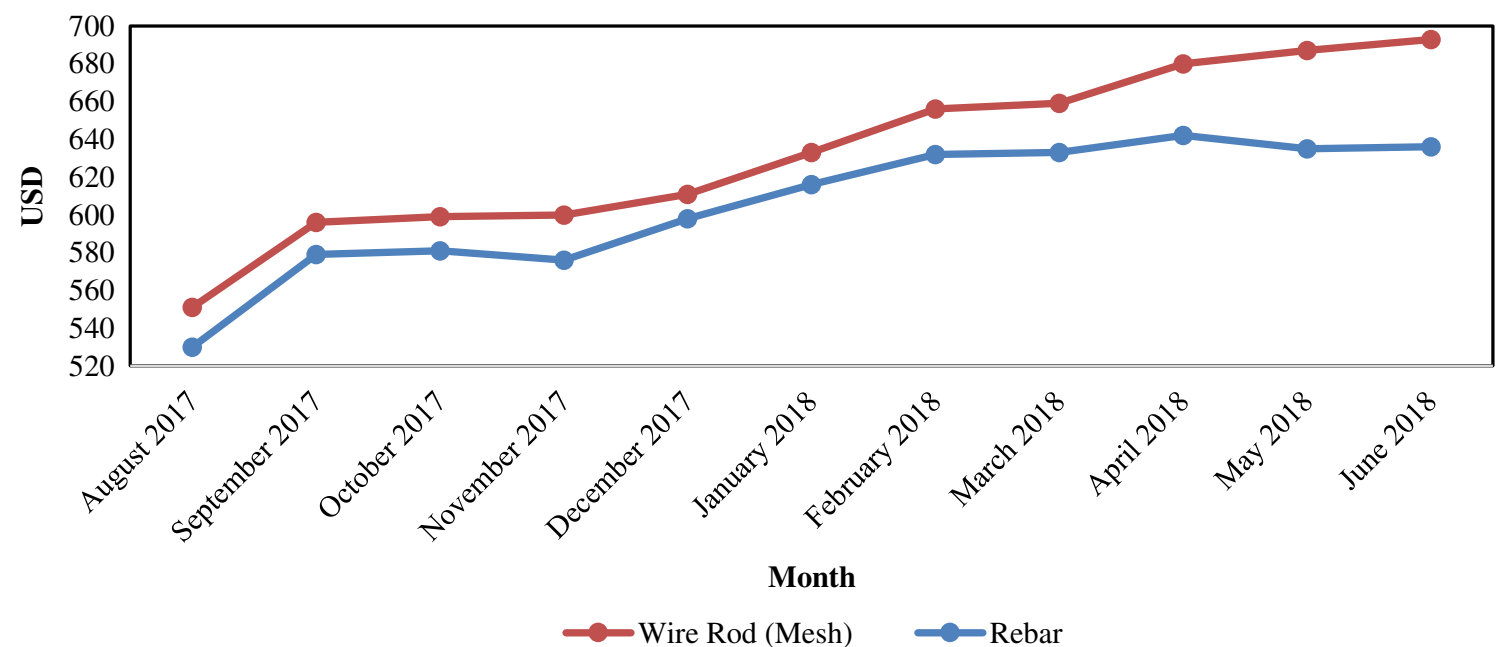

Fig. 1 Average wire rod (mesh) and rebar prices for a metric ton in the world between August 2017 and June 2018 (MEPS - World Carbon Steel Prices 2018) 


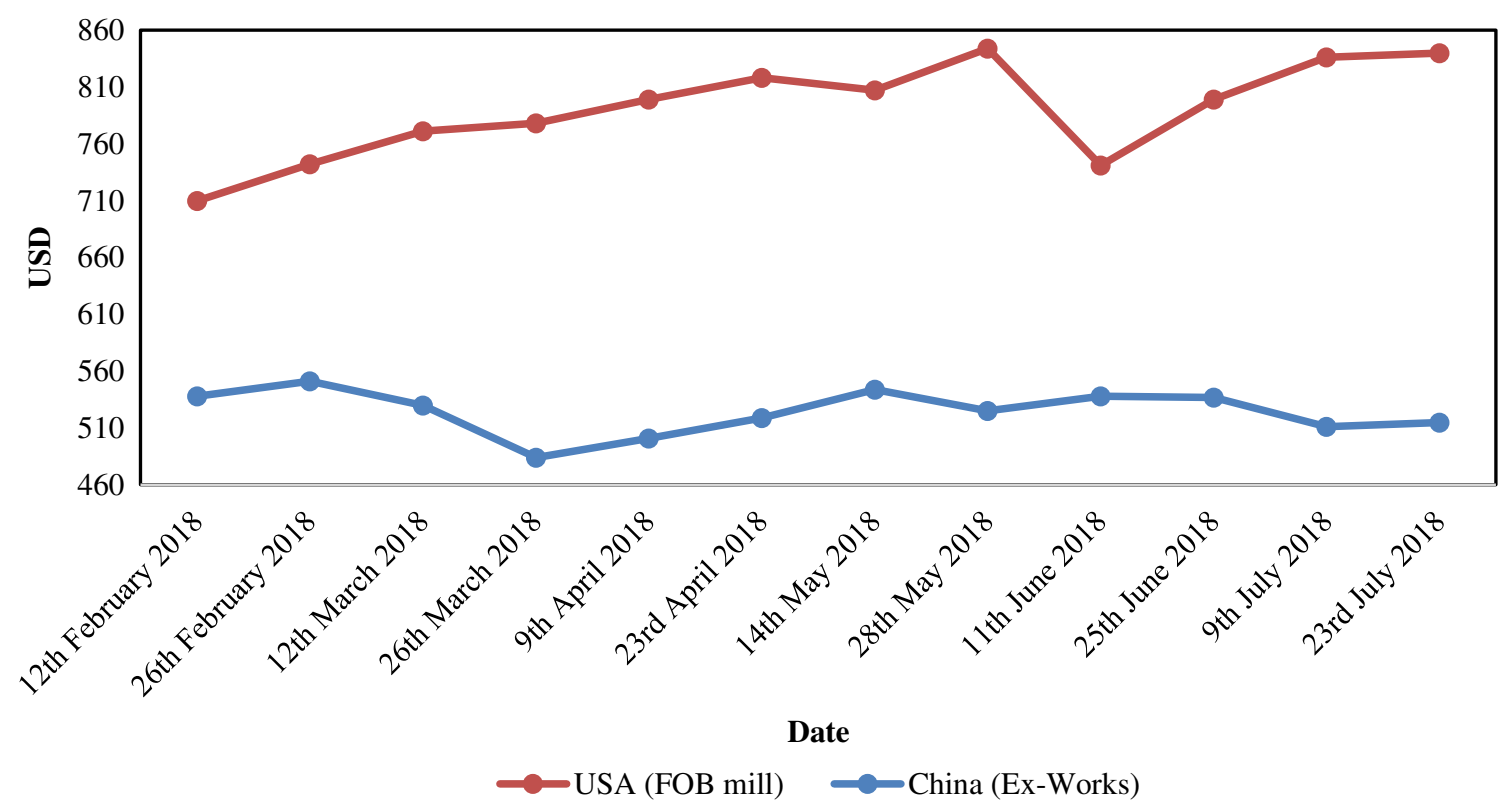

Fig. 2 Rebar price comparison in dollars for a metric ton between February 2018 and July 2018 on the US and Chinese markets (Steel Benchmarker Price History Tables and Charts 2018)

1. EXW (Ex-Works) means the seller delivers when it places the goods at the disposal of the buyer at the seller's premises or at another named place (i.e., works, factory, and warehouse). The seller does not need to load the goods on any collecting vehicle, nor does it need to clear the goods for export, where such clearance is applicable.

2. FOB (free on board) means that the seller delivers the goods on board the vessel nominated by the buyer at the named port of shipment or procures the goods already delivered. The risk of loss of or damage to the goods passes when the goods are on board the vessel, and the buyer bears all costs from that moment onwards (International Chamber of Commerce 2018).

When comparing steel prices, for example, between the US and Chinese or West European markets, the terms FOB mill and Ex-Works are treated equivalently. In the world export market, there is the concept of FOB port of export. The difference in the price of rebar in the period between February 2018 and July 2018 between the American and the Chinese markets is shown in Fig. 2 (Steel Benchmarker Price History Tables and Charts 2018).

Differences in the price of the rebar also affect the price of the prestressing strands. The prices of the prestressing strands offered on the Chinese market vary between approximately $\$ 550$ and $\$ 900$ dollars per metric ton.

\section{Optimization of reinforcement steel supply}

One of the basic problems occurring in the logistics processes of the precast concrete industry is the linking of reinforcement steel houses with the concrete plants. The precast concrete plant's task is to optimize the

Table 4 Total purchase and transport costs $a_{i j k}$ of steel reinforcement type $k$ from the steel warehouses $j$ to the precast concrete plant $i$ (USD/ton)

Steel reinforcement type $k$ Precast concrete plant $i$

\begin{tabular}{|c|c|c|c|c|c|c|c|c|c|c|c|c|c|c|c|c|}
\hline & \multicolumn{4}{|l|}{$\mathrm{CP} 1$} & \multicolumn{4}{|l|}{$\mathrm{CP} 2$} & \multicolumn{4}{|l|}{$\mathrm{CP} 3$} & \multicolumn{4}{|l|}{$\mathrm{CP} 4$} \\
\hline & \multicolumn{16}{|c|}{ Steel warehouse $j$} \\
\hline & W1 & W2 & W3 & W4 & W1 & W2 & W3 & W4 & W1 & W2 & W3 & W4 & W1 & W2 & W3 & W4 \\
\hline 8-mm ribbed steel bar & 600 & 580 & 620 & 630 & 590 & 600 & 650 & 650 & 580 & 620 & 600 & 590 & 610 & 590 & 640 & 640 \\
\hline 12-mm ribbed steel bar & 550 & 530 & 570 & 580 & 540 & 550 & 580 & 580 & 520 & 570 & 550 & 540 & 560 & 520 & 590 & 590 \\
\hline 6-mm plain steel bar & 510 & 550 & 520 & 540 & 530 & 560 & 535 & 535 & 520 & 545 & 545 & 505 & 535 & 565 & 525 & 560 \\
\hline Wire rod (mesh) & 610 & 630 & 640 & 660 & 640 & 590 & 625 & 670 & 585 & 635 & 615 & 630 & 605 & 675 & 645 & 650 \\
\hline 7-wire strand $(12.7 \mathrm{~mm})$ & 830 & 850 & 825 & 875 & 680 & 725 & 755 & 805 & 710 & 780 & 770 & 820 & 690 & 650 & 790 & 730 \\
\hline
\end{tabular}


Table 5 Percentage precast concrete plant demand $i$ for steel reinforcement type $k(\%)$

\begin{tabular}{llllll}
\hline $\begin{array}{l}\text { Precast concrete } \\
\text { plant } i\end{array}$ & \multicolumn{5}{l}{ Steel reinforcement type $k$} \\
\cline { 2 - 6 } & $\begin{array}{l}\text { 8-mm ribbed } \\
\text { steel bar }\end{array}$ & $\begin{array}{l}\text { 12-mm ribbed } \\
\text { steel bar }\end{array}$ & $\begin{array}{l}\text { 6-mm plain } \\
\text { steel bar }\end{array}$ & $\begin{array}{l}\text { Wire rod } \\
\text { (mesh) }\end{array}$ & $\begin{array}{l}\text { 7-wire strand } \\
(12.7 \mathrm{~mm})\end{array}$ \\
\hline $\mathrm{CP} 1$ & 14 & 20 & 31 & 20 & 15 \\
$\mathrm{CP} 2$ & 13 & 17 & 33 & 22 & 15 \\
$\mathrm{CP} 3$ & 18 & 16 & 37 & 21 & 8 \\
$\mathrm{CP} 4$ & 11 & 26 & 24 & 20 & 19 \\
\hline
\end{tabular}

connections so that the demand for steel reinforcement can be met at the lowest costs of purchasing and transporting them. In this paper, four concrete plants ( $i=1,2,3,4)$ have been selected to which the steel reinforcement must be delivered from four steel warehouses $(j=1,2,3,4)$, on which there are five types of reinforcement $(k=1,2,3,4,5)$ with the different shapes and dimensions of the cross sections. There are two diameters accounting for $8 \mathrm{~mm}$ and $12 \mathrm{~mm}$ of the ribbed steel bars and one diameter accounting for $6 \mathrm{~mm}$ of the plain steel bar, the wire rod (mesh), and the 7-wire strand for prestressed concrete elements. Total purchase and transport costs of the selected steel reinforcement type $k$ from the given steel warehouse $j$ to the precast concrete plant $i$ are presented in Table 4 .

Considering the conditions presented above, it should be decided how many tons of steel reinforcement should be ordered and delivered to each concrete plant so that the total cost is minimal.

In addition, the percentage demand for steel reinforcement types by the precast concrete plants, presented in Table 5, should be taken into account. The total resource steel reinforcement in steel warehouses $j$ accounts for $\mathrm{W} 1=1000$ tonnes, W2 $=2700$ tonnes, W3 = 2900 tonnes, and W4 $=1400$ tonnes, and the total precast concrete plant $i$ demands for steel reinforcement are
Fig. 3 Proceeding steps for determining the minimum cost of steel reinforcement purchase and transport
I. Defining ingredients in the formulas.

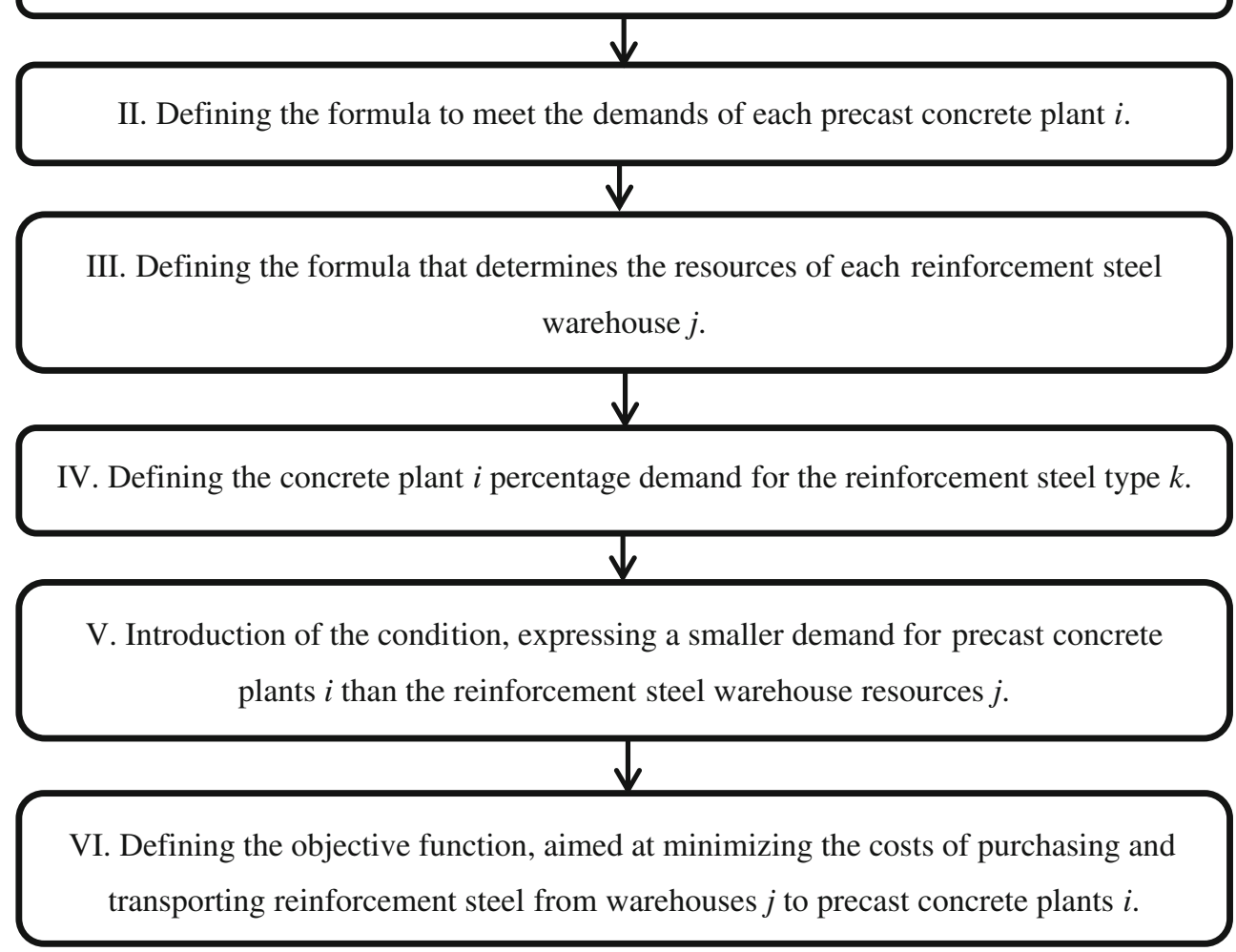


Table 6 The tonnage of steel reinforcement to be ordered from steel warehouses $j$ and delivered to precast concrete plants $i$ (tonnes)

\begin{tabular}{lrrrrr}
\hline $\begin{array}{l}\text { Precast concrete } \\
\text { plant } i\end{array}$ & \multicolumn{5}{l}{ Steel warehouse $j$} \\
\cline { 2 - 6 } & W1 & \multicolumn{1}{c}{ W2 } & W3 & W4 & Total \\
\hline CP1 & 0.00 & 660.00 & 1240.00 & 0.00 & 1900.00 \\
CP2 & 330.00 & 1144.00 & 726.00 & 0.00 & 2200.00 \\
CP3 & 350.00 & 0.00 & 550.00 & 1400.00 & 2300.00 \\
CP4 & 320.00 & 896.00 & 384.00 & 0.00 & 1600.00 \\
Total & 1000.00 & 2700.00 & 2900.00 & 1400.00 & 8000.00 \\
\hline
\end{tabular}

the following: $\mathrm{CP} 1=1900$ tonnes, $\mathrm{CP} 2=2200$ tonnes, $\mathrm{CP} 3=2300$ tonnes, and CP4 $=1600$ tonnes.

\section{Mathematical description of a case study}

The research problem presented in this paper can be solved by the linear programming method (Radzikowski and SarjuszWolski 1994) in the following six steps (Fig. 3).

Step I includes the following formula ingredients:

$a_{i j k}$ - the total purchase and transport cost of the steel reinforcement unit $X$ of the steel reinforcement type $k$ from the steel warehouse $j$ to the precast concrete plant $i$ $b_{j}$ - the available number of tons of steel reinforcement $X$ in the steel warehouse $j$

$c_{l}$ - the required number of tons of steel reinforcement $X$ in the precast concrete plant $i$

$d_{i k}$-the percentage demand of the precast concrete plants $i$ for steel reinforcement type $k$

$x_{i j}$ the number of steel reinforcement units $X$ delivered from the steel warehouse $j$ to the precast concrete plant $i$ (decision variable)

Step II refers to meeting the demands of each precast concrete plant $i$ with the following formula:

$\sum_{i=1}^{4} x_{i j}=c_{i}$, for $i=1,2,3,4$.
In step III, the formula that determines the resources of each steel warehouse $j$ is the following:

$\sum_{j=1}^{4} x_{i j}=b_{j}$, for $j=1,2,3,4$.

Step IV concerns the concrete plant $i$ percentage demand for the steel reinforcement type $k$ that is expressed by the formula:

$\sum_{k=1}^{5} d_{i k}=1$, for $k=1,2,3,4,5$

In order to solve this research problem, it is necessary to condition that the precast concrete plant demands cannot exceed the resources of the steel reinforcement warehouses, which are expressed in step V as follows:

$\sum_{i=1}^{4} c_{i} \leq \sum_{j=1}^{4} b_{j}$

Finally, in step VI, the objective function, minimizing the purchase and transportation cost of steel reinforcement, should be formulated as follows:

$\sum_{i=1}^{4} \sum_{j=1}^{4} \sum_{k=1}^{5} a_{i j k} x_{i j} d_{i k} \rightarrow$ minimum

wherein $\mathrm{x}_{i j} \geq 0$, for $i=1,2,3,4$ and $j=1,2,3,4$.

\section{Results achieved}

After completing all the six steps and using the linear programming, the following results were obtained, as shown in Table 6.

The total steel reinforcement resources are equal to the total demands of the precast concrete plants and account for 8000 tonnes. Therefore, condition 4 is met. Considering the

Table 7 The tonnage of steel reinforcement types and dimensions of the cross sections to be ordered from steel warehouses $j$ and delivered to precast concrete plants $i$ (tonnes)

\begin{tabular}{|c|c|c|c|c|c|c|}
\hline \multirow{2}{*}{$\begin{array}{l}\text { Precast concrete } \\
\text { plant } i\end{array}$} & \multicolumn{6}{|c|}{ Steel reinforcement type $k$} \\
\hline & 8-mm ribbed steel bar & 12-mm ribbed steel bar & 6-mm plain steel bar & Wire rod (mesh) & 7-wire strand $(12.7 \mathrm{~mm})$ & Total \\
\hline CP1 & 266.00 & 380.00 & 589.00 & 380.00 & 285.00 & 1900.00 \\
\hline $\mathrm{CP} 2$ & 286.00 & 374.00 & 726.00 & 484.00 & 330.00 & 2200.00 \\
\hline $\mathrm{CP} 3$ & 414.00 & 368.00 & 851.00 & 483.00 & 184.00 & 2300.00 \\
\hline $\mathrm{CP} 4$ & 176.00 & 416.00 & 384.00 & 320.00 & 304.00 & 1600.00 \\
\hline Total & 1142.00 & 1538.00 & 2550.00 & 1667.00 & 1103.00 & 8000.00 \\
\hline
\end{tabular}


Table 8 Minimum steel reinforcement purchase and transportation costs from steel warehouse $j$ to the precast concrete plants $i$ (USD)

\begin{tabular}{lrrrrr}
\hline Precast concrete plant $i$ & \multicolumn{5}{l}{ Steel warehouse $j$} \\
\cline { 2 - 6 } & \multicolumn{1}{l}{ W1 } & \multicolumn{1}{l}{ W2 } & W3 & W4 & \multicolumn{1}{c}{ Total } \\
\hline CP1 & 0.00 & $364,500.00$ & $775,645.00$ & 0.00 & $1,140,145.00$ \\
CP2 & $224,400.00$ & $662,860.00$ & $388,410.00$ & 0.00 & $1,275,670.00$ \\
CP3 & $204,750.00$ & 0.00 & $351,625.00$ & $746,915.00$ & $1,303,290.00$ \\
CP4 & $193,600.00$ & $517,760.00$ & $201,600.00$ & 0.00 & $912,960.00$ \\
Total & $622,750.00$ & $1,545,120.00$ & $1,717,280.00$ & $746,915.00$ & $4,632,065.00$ \\
\hline
\end{tabular}

steel reinforcement types and dimensions of the cross sections and the demands of the precast concrete plants, the optimal tonnage of orders and deliveries is presented in Table 7.

The calculation was carried out by means of the Microsoft Excel 2013 spreadsheet solver. Nonnegative values for unrestricted variables were taken into account during the calculation process.

\section{Conclusion}

The study established proceeding steps in steel reinforcement purchase and transportation procurement from different steel warehouses to precast concrete plants, considering optimization in terms of cost. In order to search for an optimal procurement strategy, meeting the minimum purchase and transportation costs while limiting the steel reinforcement resources and the precast concrete plants' demand, a linear programming was applied. For experimental purposes, a case study of four precast concrete plants and four steel reinforcement warehouses was used. Steel reinforcement was divided into the following five different types: $8-\mathrm{mm}$ ribbed steel bar, 12$\mathrm{mm}$ ribbed bar, 6-mm plain steel bar, wire rod (mesh), and 7wire strand $(12.7 \mathrm{~mm})$. Types of such reinforcement find application in a very large number of production plants of reinforced concrete and prestressed construction elements. Prices of ribbed, plain, and 7-wire strand reinforcement were selected on the basis of steel price analyses on global markets. In addition, the prices of structural reinforcement, including the American and Chinese markets in the Ex-Works and free on board modes of transport, were analyzed. This allowed examining the tendency of steel prices to change over months in different markets and its reference to global conditions. The optimal strategy of steel reinforcement purchase and transportation considering the lowest possible costs is presented in Table 8 .

Finally, the optimized purchase and transportation strategy, including overall and varied percentage of steel reinforcement types and cross-section demands by each precast concrete plant, was achieved with the lowest costs accounting for $4,632,065.00$ USD. The calculations had an assumption that variables can only be natural numbers, including zero. The results show that the adopted assumptions to optimize purchase and transportation of steel reinforcement are effective. The presented model of proceeding, based on six subsequent steps, is a practical and clear procedure for the decisionmaking processes concerning steel purchases for the production needs of reinforced and prestressed concrete elements. It is necessary to consider the variability of conditions under which precast concrete plants and steel warehouses are operating. It is strictly related to diversified conditions regarding the supply and demand on the construction market, which affect, i.e., the level of price volatility. Attention should also be paid to state regulations regarding transportation, taxation of steel in international trade, currency exchange rates, and other risks. It seems, therefore, necessary to supplement the decision-making and optimization models with a probabilistic-statistical approach. For this purpose, the application of simulation methods that determine orders in variable conditions should also be taken into account.

Open Access This article is distributed under the terms of the Creative Commons Attribution 4.0 International License (http:// creativecommons.org/licenses/by/4.0/), which permits unrestricted use, distribution, and reproduction in any medium, provided you give appropriate credit to the original author(s) and the source, provide a link to the Creative Commons license, and indicate if changes were made.

\section{References}

Bielawski J, Cieszyński K, W S (1982) Przemystowa Produkcja Prefabrykatów - Technologia Zbrojenia Elementów. Państwowe Wydawnictwo Naukowe, Warszawa

Chan WT, Hu H (2002) Production scheduling for precast plants using a flow shop sequencing model. J Comput Civ Eng 16(3):1605-1616

Chin S, Yoon S, Kim Y, Ryu J, Choi C (2005) Realtime 4D CAD + RFID for project progress management. Proceedings of Construction Research Congress, San Diego California, pp 33-43

Dawood NN. (1993). Knowledge elicitation and dynamic scheduling using a simulation model: an application to the precast manufacturing process. In Proceedings of the Civil-Comp93 (p. 73)

European Committee for Standardization. (2000a). PrEN 10138-1:2000 Prestressing steels - part 1: general requirements. Belgium

European Committee for Standardization. (2000b) PrEN 10138-3:2000 Prestressing steels - part 3: strand. Belgium 
European Committee for Standardization. (2008). EN-1992-1-1 Eurocode 2: design of concrete structures - part 1-1: general rules and rules for buildings. Belgium

Foremny A, Nicał A (2013) Building information modeling : stan obecny i kierunki rozwoju. Autobusy: Technika, Eksploatacja, Systemy Transportowe 14:1759-1766 Retrieved from http:// yadda.icm.edu.pl/baztech/element/bwmeta1.element.baztech$60 \mathrm{f} 84 \mathrm{fbb}-\mathrm{a} 4 \mathrm{db}-4 \mathrm{~d} 3 \mathrm{e}-9 \mathrm{ac} 6-00565 \mathrm{f} 0 \mathrm{a} 8 \mathrm{c} 96$; j sessionid= 7AF460E1B969E7C807CB5B1E6F6CD5EF. Accessed 13 Nov 2018

Grzyl B, Miszewska-Urbańska E, Apollo M (2017) Building information modelling as an opportunity and risk for stakeholders involved in construction investment process. Procedia Eng 196(June):10261033. https://doi.org/10.1016/j.proeng.2017.08.045

Ibadov N (2016) Determination of the risk factors impact on the construction projects implementation using fuzzy sets theory. Acta Phys Pol A 130(1):107-111. https://doi.org/10.12693/APhysPolA.130.107

Ibadov N (2018). Construction project planning under fuzzy time constraint. Int J Environ Sci Technol doi:https://doi.org/10.1007/ s13762-018-1695-x

International Chamber of Commerce. (2018). Retrieved November 13, 2018, from https://iccwbo.org/. Accessed 13 Nov 2018

Jankowski C, Antkiewicz J (2018). Koszt wykonania fundamentów. Retrieved November 27, 2018, from https://www.budujemydom. pl/fundamenty-i-piwnice/10866-koszt-wykonania-fundamentow. Accessed 27 Nov 2018

Jaselskis EJ, El-Misalami T (2003) Implementing radio frequency identification in the construction process. J Constr Eng Manag 129(6): 680-688. Retrieved from. https://doi.org/10.1061/(ASCE)07339364(2003)129:6(680

Konsorcjum Stali SA Welded meshes offer. (2018). Retrieved November 12, 2018, from http://www.konsorcjumstali.com.pl. Accessed 12 Nov 2018

MEPS - World Carbon Steel Prices. (2018). Retrieved November 12, 2018, from http://www.meps.co.uk. Accessed 12 Nov 2018

Nicał AK (2018a). Optimization of aggregates supply for concrete plants, archives of civil engineering. (Manuscript submitted for publication)

Nicał AK (2018b). Enhancing lean concept in precast concrete manufacturing with advanced material requirements planning system. In Creative Construction Conference Proceedings (pp. 453-
458). Diamond Congress Ltd. doi:https://doi.org/10.3311/ CCC2018-060

Nicał AK, Wodyński W (2016) Enhancing facility management through BIM 6D. Procedia Eng 164:299-306. https://doi.org/10.1016/j. proeng.2016.11.623

Radzikowski W, Sarjusz-Wolski Z (1994) Metody Optymalizacji Decyzji Logistycznych. Toruńska Szkoła Zarządzania, Torun

Radziszewska-Zielina E, Kania E (2017). Selection of the order of the construction of structures of a multiple-structure project, taking into account time-cost optimisation. ASME PRESS, 167-177

Sangyoon C, Suwon Y, Cheolho C, Changyon C (2008). RFID+4D CAD for progress management of structural steel works in high-rise buildings. J Comput Civ Eng, 22(2). Retrieved from doi:https://doi.org/ 10.1061/(ASCE)0887-3801(2008)22:2(74)

Shin TH, Chin S, Yoon SW, Kwon SW (2011) A service-oriented integrated information framework for RFID/WSN-based intelligent construction supply chain management. Autom Constr 20(6):706715. https://doi.org/10.1016/j.autcon.2010.12.002

Song J, Haas CT, Caldas C, Ergen E, Akinci B (2006) Automating the task of tracking the delivery and receipt of fabricated pipe spools in industrial projects. Autom Constr 15:166-177. https://doi.org/10. 1016/j.autcon.2005.03.001

Steel Benchmarker Price History Tables and Charts. (2018). Retrieved November 13, 2018, from https://www.steelbenchmarker.com. Accessed 13 Nov 2018

Toklu MC (2018) Interval type-2 fuzzy TOPSIS method for calibration supplier selection problem: a case study in an automotive company. Arab J Geosci Retrieved from 11:341. https://doi.org/10.1007/ s12517-018-3707-z

Więch P (2013). Nowoczesne stale zbrojeniowe w budownictwie krajowym. Inżynier Budownictwa, (12), 58-63

Yagi J, Arai E, Arai T (2005) Parts and packets unification radio frequency identification application for construction. Autom Constr 14: 477-490. https://doi.org/10.1016/j.autcon.2004.09.005

Zhiliang M, Zhitian Y. (2015). Application of information technology in precast production: a literature review and future directions. In The Second International Conference on Civil and Building Engineering Informatics. Tokyo

Żmuda J (2016) Projektowanie Konstrukcji Stalowych, I edn. Wydawnictwo Naukowe PWN SA, Warszawa 